\title{
New floristic records from Central Europe 3 (reports 13-40)
}

\author{
Matej Dudášs ${ }^{1}$ (ed.), Pavol Eliáš sen. ${ }^{2}$, Vlastimil Mikolášs ${ }^{3}$, Peter Turis ${ }^{4}$ \& Ingrid Turisová ${ }^{5}$ \\ ${ }^{1}$ Department of Botany, Institute of Biology \& Ecology, Faculty of Science, P. J. Šafárik University, \\ Mánesova 23, SK-041 54, Košice, Slovakia, dudas.mato@gmail.com \\ 2 Generála Goliána 8, SK-97102, Trnava, Slovakia, pavol.elias149@gmail.com \\ ${ }^{3}$ Hanojská 4, SK-040 13, Košice, Slovakia, dolomiticola@gmail.com \\ ${ }^{4}$ The Low Tatras National Park Administration, Lazovná 10, SK-974 04, Banská Bystrica, Slovakia, \\ peter.turis@sopsr.sk \\ ${ }^{5}$ Matej Bel University in Banská Bystrica, Faculty of Natural Sciences, Tajovského 40, SK-974 01, \\ Banská Bystrica, Slovakia, ingrid.turisova@umb.sk
}

Dudáš M. (ed.), Eliáš P., Mikoláš V., Turis P., Turisová I. (2019): New floristic records from Central Europe 3 (reports 13-40). - Thaiszia - J. Bot. 29 (1): 101-110.

Abstract:Thethird part of the seriesincludes 28new chorological records of vascular plants from Austria, Czechia, Slovakia, Transcarpathian Ukraine and Romania. From Austria, new record of Hyoscyamus niger was reported. In Czechia in the Bílé Karpaty Mts., new sites of Corydalis lutea, Ranunculus arvensis and Thlaspi perfoliatum were recorded. In eastern Slovakia, two neophyte species Robinia viscosa and Pyrethrum parthenium were found and the new altitudinal maximum for halophyte species Taraxacum bessarabicum in $418 \mathrm{~m}$ above sea level was recorded. In the Ukrainian Carpathians, new sites of Lycopodium alpinum and Phyteuma vagneri in the massif of the Polonina Krasna were found as well as new records of Aronia melanocarpa and Inula helenium in the valley of the Latorica river. From the Romanian Carpathians, Festuca stricta subsp. saxatilis, Pulmonaria filarszkyana, Saxifraga luteoviridis and Silene zawadzkii in the Maramureş Mts. were recorded as well as rare orchid Ophrys insectifera from Retezat Mts.

Keywords: chorology, vascular plants, Austria, Czechia, Slovakia, Transcarpathian Ukraine, Romania, new reports, Bílé Karpaty Mts., Eastern Carpathians, Maramureş Mts., Retezat Mts., Red list species. 
This is an ongoing report in the newly established series dealing with the new chorological data on higher vascular plants in Central Europe. The paper includes also the findings from the adjacent Romanian Carpathians. Due to the fact that Romania was previously not included in the agreed countries according to the paragraph 4 (for details, see Thaiszia - J. Bot. 28 (1), pp. 79-80, 2018), the Editorial board decided to accept floristics reports also from the adjacent parts of the Romanian Carpathians (abbreviation RO), which are the part of the Eastern Carpathians continued to the easternmost part of Slovakia. The nomenclature of the taxa follows the Euro+Med PlantBase (Euro+Med 2006-) and/or Checklist of Non-Vascular and Vascular Plants of Slovakia (Marhold \& Hindák 1998). The nomenclature of vegetation units follows Sanda et al. (2008).

The publication includes contributions by M. Dudáš (13-17), M. Dudáš \& V. Mikoláš (18), P. Eliáš sen. (19-32), P. Turis \& I. Turisová (33-40) arranged alphabetically.

\section{Matej Dudáš (reports 13-17)}

\section{$\underline{A U}$}

13. Hyoscyamus niger L.: Niederösterreich, Mistelbach county, Zwingendorf, Pulkautal Strasse, edge of field (with potato) in the direction to Wulzeshofen, over ten flowering plants, ca. $183 \mathrm{~m}, 48^{\circ} 42^{\prime} 18.5^{\prime \prime} \mathrm{N} 16^{\circ} 16^{\prime} 34.6^{\prime \prime} \mathrm{E}, 17.7$. 2018, M. Dudáš, KO (no. 34399).

\section{$\underline{\text { SK }}$}

14. Huperzia selago (L.) Bernh. ex Schrank et Mart.: the Slanské vrchy Mts., Hlinné, Praporec Hill, northern slope near green tourist path, the edge of the beech forest (Fagus sylvatica) and the forest road, ca. $870 \mathrm{~m}, 48^{\circ} 56^{\prime} 35^{\prime \prime} \mathrm{N}$ $21^{\circ} 29^{\prime} 18^{\prime \prime} E, 7094 d, 29.6$. 2018, M. Dudáš, KO (no. 34408).

This species grows on few places mainly in the northern part of the mountain (Dostál 1976, 1981) while in the central part it is rare and from the southern part the distribution data are missing.

15. Pyrethrum parthenium (L.) Sm. (syn. Tanacetum parthenium (L.) Sch. Bip.): the basins Spišské kotliny (Hornádska kotlina Basin), Spišské Tomášovce, Kostolná Street, escaped from cultivation around the church, tens of flowering plants under the walls and in the gaps in the paths, $529 \mathrm{~m}, 7088 \mathrm{~b}, 29.8$. 2018, M. Dudáš, photographed. 
According to Medvecká et al. (2012), the species is considered as casual neophyte in the Slovak flora.

16. Robinia viscosa Vent.: the Zemplínske vrchy Mts., Malá Bara, escaped from cultivation near the cemetery on an area over $50 \mathrm{~m}^{2}, 152 \mathrm{~m}, 7596 \mathrm{c}, 14.7 .2018$, M. Dudáš, observation. - the Zemplínske vrchy Mts., Malá Tŕňa, Královka St., along the road in the length ca. $50 \mathrm{~m}$ southeast from the edge of village, ca. 175 m, 7596c, 14. 7. 2018, M. Dudáš, observation.

According to Medvecká et al. (2012), the species is considered as naturalized neophyte in the Slovak flora.

\section{TUA}

17. Inula helenium L.: Zakarpats'ka oblast, Uzhorodskyj rajon, the edge of the pasture between the villages of Syurte and Haloch, ca. ten flowering plants, $102 \mathrm{~m}, 7499 \mathrm{c}, 48^{\circ} 31^{\prime} 41.7^{\prime \prime} \mathrm{N} 22^{\circ} 12^{\prime} 48.5^{\prime \prime} \mathrm{E}, 1.10 .2017$, M. Dudáš, BRNU (no. 656734). - Haloch, wet ditch on the southern part of the village, five flowering plants, $102 \mathrm{~m}, 7499 \mathrm{c}, 48^{\circ} 32^{\prime} 44.7^{\prime \prime} \mathrm{N} 22^{\circ} 11^{\prime} 39.5^{\prime \prime} \mathrm{E}$ ( $\pm 50 \mathrm{~m}$ ), July 2017, M. Dudáš, observation.

\section{Matej Dudáš \& Vlastimil Mikoláš (report 18)}

\section{SK}

18. Taraxacum bessarabicum (Hornem.) Hand.-Mazz.: Stredné Pohornádie Valley, Košice, Kavečany, the bus stop "ZOO" near the Zoological garden Košice, frequent on the trampled site around the bus stop, tens of flowering plants, 418 m, 4846'51"N 21ํ12'09"E, 7293a, 30. 9. 2001, V. Mikoláš, KO: 33920; 19. 9. 2017, M. Dudáš, KO: 33810; October 2018, M. Dudáš, photographed.

This is the new altitudinal maximum for the species in the area of Slovakia in the altitude $418 \mathrm{~m}$ a.s.l. and at the same time the first occurrence in the area of Carpathian flora (Carpaticum). Previously published localities in the city of Košice were recorded in the altitude between $209-223 \mathrm{~m}$ a.s.l. (Dudáš et al. 2016). In the seasons 2017 and again in 2018 many flowering plants and sterile leaf rosettes were confirmed there. Plants growing and flowering here on the trampled gravel sites around the bus stop in poor vegetation cover (with Lolium perenne as a dominants and other species as Achillea millefolium, Matricaria discoidea and Plantago major), on the edge of the nearest field road, on the paths and in the gaps between the curb stones on the edge of the parking lot. The 
origin of this isolated population is not clear, diaspores were probably introduced with the gravel from Magnezitárska Street during the terrain modifications.

\section{Pavol Eliáš sen. (reports 19-32)}

\section{$\underline{\mathrm{CZ}}$}

19. Astrantia major L.: the Bílé Karpaty Mts., Hostětín, Jahodisko, SW of the the village, hornbeam forest $W$ of the road Pitín-Hostětín (No. 49), 6973c, 18. 5. 2013, P. Eliáš sen., record.

The species has been recorded in many localities in the Mts. (Jongepier \& Jongepierová 2006; Jongepier \& Pechanec 2006). This is a new record for the area.

20. Bromus tectorum L.: the Bílé Karpaty Mts., Hostětín, railway stop NW of the village, 6973a, 17. 5. 2013, P. Eliáš sen., record.

The species has been recorded in the southern and the northern parts of the Mts. (Jongepier \& Jongepierová 2006; Jongepier \& Pechanec 2006). This is a new record for the area in the central part.

21. Caltha palustris L.: the Bílé Karpaty Mts., Hostětín, village, at the Kolelač brook in the village, more flowering plants, $384 \mathrm{~m}, 49^{\circ} 2^{\prime} 50^{\prime \prime} \mathrm{N}, 17^{\circ} 52^{\prime} 45^{\prime \prime} \mathrm{E}$, 6973a/c, 17. 5. 2013, P. Eliáš sen., record.

The species has been recorded in many localities in the Mts. (Jongepier \& Jongepierová 2006; Jongepier \& Pechanec 2006). This is a new record for the area.

22. Corydalis lutea (L.) DC.: the Bílé Karpaty Mts., Hostětín, the road to the railway stop NW of the village, some flowering plants on the wall in front of the family house no. $67,384 \mathrm{~m}, 49^{\circ} 2^{\prime} 50^{\prime \prime} \mathrm{N}, 17^{\circ} 52^{\prime} 45^{\prime \prime} \mathrm{E}, 6973 \mathrm{a}, 17.5 .2013$, P. Eliáš sen., record.

This species is alien in the Czech Republic which has been introduced into the area by human activity. Few localities only were recorded in the Mts. (Jongepier \& Pechanec 2006; Jongepier et al. 2007). This is a new record for the area.

23. Hacquetia epipactis (Scop.) DC.: the Bílé Karpaty Mts., Hostětín, Jahodisko, SW of the the village, hornbeam forest $W$ of the road Pitín-Hostětín (No. 49), 6973c, 18. 5. 2013, P. Eliáš sen., record. 
The species has been recorded in many localities in the Mts. (Jongepier \& Jongepierová 2006; Jongepier \& Pechanec 2006). This is a new record for the area.

24. Impatiens parviflora DC.: the Bílé Karpaty Mts., Hostětín, SE of the village, Kozlice hill, tourist road "Na okolo Hostětína", the stop at two old oaks, ca 400 m, 6973c, 18. 5. 2013, P. Eliáš sen., record.

In the last years this alien species has been recorded in many localities in the Mts. (Jongepier \& Jongepierová 2006; Jongepier \& Pechanec 2006). This is a new record for the area.

25. Lamium album L.: the Bílé Karpaty Mts., Hostětín, near the field road to the railway stop, NW of the village, 6973a, 17. 5. 2013, P. Eliáš sen., record.

The species has been recorded in several localities in the Mts. (Jongepier \& Jongepierová 2006; Jongepier \& Pechanec 2006). This is a new record for the area.

26. Mercurialis perennis L.: the Bílé Karpaty Mts., Hostětín, Jahodisko, SW of the village, hornbeam forest W of the road Pitín-Hostětín (No. 49), 6973c, 18. 5. 2013, P. Eliáš sen., record.

The species has been recorded in many localities in the Mts. (Jongepier \& Jongepierová 2006; Jongepier \& Pechanec 2006). This is a new record for the area.

27. Polygonatum multiflorum (L.) All.: the Bílé Karpaty Mts., Hostětín, Jahodisko, SW of the village, hornbeam forest W of the road Pitín-Hostětín (No. 49), 6973c, 18. 5. 2013, P. Eliáš sen., record.

The species has been recorded in many localities in the Mts. (Jongepier \& Jongepierová 2006; Jongepier \& Pechanec 2006). This is a new record for the area.

28. Polygonatum verticillatum (L.) All.: the Bílé Karpaty Mts., Hostětín, Jahodisko, SW of the village, hornbeam forest W of the road Pitín-Hostětín (No. 49), 6973c, 18. 5. 2013, P. Eliáš sen., record.

The species has been recorded in some localities in the Mts. (Jongepier \& Jongepierová 2006; Jongepier \& Pechanec 2006). This is a new record for the area.

29. Potentilla anserina L.: the Bílé Karpaty Mts., Hostětín, near the field road to the railway stop, NW of the village, 6973a, 17. 5. 2013, P. Eliáš sen., record. 
The species has been recorded in many localities in the Mts. (Jongepier \& Jongepierová 2006; Jongepier \& Pechanec 2006). This is a new record for the area.

30. Ranunculus arvensis L.: the Bílé Karpaty Mts., Hostětín, Jahodisko, SW of the village, arable field $W$ of the road Pitín-Hostětín (No. 49), 6973c, 18. 5. 2013, P. Eliáš sen., record.

The species has been recorded in several localities in the Mts. (Jongepier \& Jongepierová 2006; Jongepier \& Pechanec 2006). This is a new record for the area.

31. Reseda lutea L.: the Bílé Karpaty Mts., Hostětín, railway stop, NW of the village, 6973a, 17. 5. 2013, P. Eliáš sen., record.

The species has been recorded in several localities in the Mts. (Jongepier \& Jongepierová 2006; Jongepier \& Pechanec 2006). This is a new locality for the area.

32. Thlaspi perfoliatum L.: the Bílé Karpaty Mts., Hostětín, railway stop, NW of the village, 6973a, 17. 5. 2013, P. Eliáš sen., record.

This species has been recorded in several localities in the Mts. (Jongepier \& Jongepierová 2006; Jongepier \& Pechanec 2006). This is anew record for the area.

\section{Peter Turis \& Ingrid Turisová (reports 33-40)}

\section{$\underline{\text { TUA }}$}

33. Aronia melanocarpa (Michx.) Elliott: the Vorochtjanska Verchovina, village Chorna Tysa, peat bog Andromeda (= Chorne bagno), 48.3055869 N, 24.3466442 E, one fruiting shrub, 15. 6. 2018, leg. \& det. P. Turis \& I. Turisová, Herbarium Peter Turis.

The species, not mentioned before in this site (cf. Vorontsov et al. 2011), was probably introduced by birds.

34. Lycopodium alpinum L.: Polonina Krasna, the village Kolochava, northern slope of Krasna ridge, near the green tourist mark from the ridge to Pryslop saddle (926 m), 48.386695 N, 23.774749 E, 28. 5. 2016, leg. \& det. P. Turis, Herbarium Peter Turis. 
The massif Polonina Krasna is a part of the floristic district Gorgany, where the occurrence of this species is very rare (Chopyk 1976).

35. Phyteuma vagneri A. Kern.: Polonina Krasna, the village Kolochava, several flowering individuals next to the yellow tourist mark in the meadow under Pryslop saddle (926 m) towards the village Kolochava, $48.399811 \mathrm{~N}, 23.785038$ E, 28. 5. 2016, leg. \& det. P. Turis, Herbarium Peter Turis.

The area of this East- and Southern Carpathians endemic ends by the ridge of Polonina Bukovska in the Eastern Beskids in Ukraine near the border with Poland. In this area, it is considered as rare, while in the other parts of the Ukrainian Carpathians it is frequent (Chopyk 1976).

\section{RO}

36. Festuca stricta subsp. saxatilis (Schur) Foggi \& Signorini: the Maramureş Mts., the village Vişeu de Sus, Mt. Lostun Mic (1595 m), the end of the creek valley Ştevioara Mare near the Ukrainian-Romanian border, a distinctive grassy ridge with shallow soil and a limestone substrate protruding to the surface, ca. $900 \mathrm{~m}$ NE from the sheepfold, in the association Festucetum saxatilis Domin 1933, 47.8198789 N, 24.7855769 E, 12. 6. 2018, leg. \& det. P. Turis \& I. Turisová, Herbarium Peter Turis.

This endemic species of the East-, South- and Apuseni Carpathians is mentioned by Pawłowski \& Walas (1949) in the Romanian-Ukrainian border mountains Maramureş Mts./Chivchiny Mts. in several places, especially in the association Festucetum saxatilis Domin 1933 and Saxifrago luteoviridis-Silenetum zawadzkii Pawłowski et Walas 1949 [ut Saxifragetum luteoviridis (Pawł. 1936) Pawł. et Wal.], rarely also in Hyperico grisebachii-Calamagrostetum villosae Pawłowski et Walas 1949 [ut Calamagrostidetum pocuticum (Pawł. 1936) Pawł. et Wal.].

37. Ophrys insectifera L.: the Retezat Mts., village Câmpu lui Neag, Mt. Piule (2081 m), SE slope Piatra Alba, several flowering individuals on the top of limestone rock, $45.2916322 \mathrm{~N}, 22.9298475$ E, 3. 7. 1999, P. Turis, record.

It is a very rare and critically endangered species (category CR) in Romania. The most of the approximately 10 known localities are located in the upper reaches of the rivers lalomița, Prahova and Doftana between the cities of Braşov and Ploieşti, but it is mentioned also on Mt. Piatra lorgovanului (2014 m) in the limestone part of the Retezat Mts. (Dihoru \& Negrean 2009). 
38. Pulmonaria filarszkyana Jáv.: the Maramureş Mts., village Vişeu de Sus, Mt. Lostun Mic (1595 m), tall-herb vegetation on the alluvium of the creek Lostun, 47.8122528 N, 24.7642158 E, 12. 6. 2018, P. Turis \& I. Turisová, photographed.

An Eastern Carpathians endemic plant with relatively small area is sporadically occurring from Polonina Borzava in Ukraine (Chopyk 1976) to the Calimani Mts. and the Rarau Mts. in north Romania (Oprea 2005). In the Maramureş Mts. it is mentioned only from Mt. Farcău (1957 m), Mt. Pietrosul Maramureşului (= Mt. Pietrosul Bardău, 1850 m) and Măcărlău in the valley of Vaser River (Oprea 2005). Our locality is also located in the Vaser River basin.

39. Saxifraga luteoviridis Schott \& Kotschy: the Maramureş Mts., village Vişeu de Sus, Mt. Lostun Mic (1595 m), the end of the valley of the Ştevioara Mare creek near the Ukrainian-Romanian border, a meadow on a steep limestone slope, the locality with shallow soil and loose vegetation ca. $500 \mathrm{~m}$ NE from the sheepfold, 47.8203417 N, 24.7788794 E, 12. 6. 2018, P. Turis \& I. Turisová, record.

The area of this Carpathian-Balkan species reaches the northern margin of the Romanian-Ukrainian border mountains Maramureş/Chivchiny. In its Ukrainian part, referred to as the Chivchiny Mts., it is mentioned in three places (cf. Chornej 2005; Kobiv 2007). In the Romanian part, named the Maramureş Mts., this species is also mentioned by Pawłowski \& Walas (1949) from Mt. Lostun Mic (1595 m) in the association Festucetum saxatilis Domin 1933 [ut Festucetum saxatilis (Pawł. 1936) Pawł. et Wal.].

40. Silene zawadzkii Herbich: the Maramureş Mts., village Vişeu de Sus, Mt. Lostun Mic $(1595 \mathrm{~m})$, the end of the creek valley Ştevioara Mare near the Ukrainian-Romanian border, the distinctive limestone rock on a grassy slope ca. $1 \mathrm{~km} \mathrm{NE}$ from the sheepfold, $47.8209017 \mathrm{~N}, 24.7860489 \mathrm{E}, 12.6 .2018$, P. Turis \& I. Turisová, record.

Until recently, the species was considered endemic to the Eastern Carpathians (Kliment et al. 2016) with an area ranging from the Ukrainian Chivchiny Mts. to the Romanian Ceahlau Mts. and the Hasmas Mts. (Oprea 2005). It has recently been confirmed also in the Fagaraş Mts. in the Southern Carpathians (Bartók et al. 2016). It is mentioned at the localities Mt. Lostun Mic (1595 m) and Mt. Lostun (1654 m) by Pawłowski \& Walas (1949) and Chopyk (1976).

\section{References}

Bartók A., Hurdu B. I., Szatmari P. M., Ronikier M., Puşcaş M., Novikoff A., Bartha L. \& Vonica G. (2016): New records for the high-mountain flora of the Făgăraş 
Mts. (Southern Carpathians) with discussion on ecological preferences and distribution of studied taxa in the Carpathians. - Contr. Bot. 51: 77-153.

Dudáš M., Fabianová J., Eliáš P. jun., Dítě D. \& Dítětová Z. (2016): Occurrence and coenology of halophilous species Taraxacum bessarabicum (Hornem.) Hand.-Mazz. (sect. Piesis) in Slovakia. - Thaiszia - J. Bot. 26 (1): 41-56.

Dostál L'. (1976): Floristické poznámky a doplnky k rozšíreniu niektorých druhov

Pteridophyta na východnom Slovensku. - Zborn. Východoslov. Múz. v Košiciach, ser. AB, prír. vedy XVII: 87-98.

Dostál l'. (1981): Floristické poznámky zo Slanských vrchov l. -Zborn. Východoslov.

Múz. v Košiciach, prír. vedy XXII: 41-65.

Euro+Med (2006-): Euro+Med PlantBase - the information resource for EuroMediterranean plant diversity. Published on the Internet http://ww2.bgbm. org/EuroPlusMed/ [accessed April 2019].

Chopyk V. I. (1976): Vysokohirna flora Ukraïns'kych Karpat. - Naukova dumka, Kyïv, 270 pp.

Chornej I. I. (2005): Istorija formuvannja prirodno-zapovidnogo fondu v Čivčins'kych gorach (Ukraïns'ki Karpaty). - Zapovidna sprava v Ukraïni, 11, 2: 63-67.

Dihoru G. \& Negrean G. (2009): Cartea roşie a plantelor vasculare din România.

- Editura Academiei Române, Bucureşti, 630 pp.

Jongepier J. W. \& Jongepierová I. (2006): Komentovaný seznam cévnatých rostlin Bílých Karpat. - ZO ČSOP Bílé Karpaty, Veselí nad Moravou.

Jongepier J. W. \& Pechanec V. (2006): Atlas rozšíření cévnatých rostlin CHKO Bílé Karpaty. - ZO ČSOP Bílé Karpaty, Veselí nad Moravou, 202 pp.

Jongepier J. W., Fajmon K., Otýpková Z. (2007): Významné nálezy cévnatých rostlin v Chráněné krajinné oblasti Bílé Karpaty a v přilehlém okolí: nové druhy pro území. - Zprávy Čes. Bot. Společ., Praha, 42: 117-135.

Kliment J., Turis P. \& Janišová M. (2016): Taxa of vascular plants endemic to the Carpathian Mts. - Preslia 88: 19-76.

Kobiv J., Prokopiv A., Heleš M., Borsukevyč L. \& Nadraha M. (2007): Pošyrennja i stan populjacij ridkisnych, zahroženych ta endemičnych vydiv roslyn u pivničnij častyni prikordonnoï diljanky Čyvčyns'kych hir (Ukraïns'ki Karpaty).

- Visnyk L'viv. Univ., Ser. Biol. 45: 71-84.

Marhold K. \& Hindák F. (eds.) (1998): Zoznam nižších a vyšších rastlín Slovenska. - Veda, Bratislava, 687 pp.

Medvecká J., Kliment J., Májeková J., Halada L'., Zaliberová M., Gojdičová E., Feráková V. \&

Jarolímek I. (2012): Inventory of the alien flora of Slovakia. - Preslia 84: 257-309. 
Oprea A. (2005): Lista critică a plantelor vasculare din România. - Editura Universității „Alexandru Ioan Cuza“, Iaşi, 668 pp.

Pawłowski B. \& Walas J. (1949): Les asociations des plantes vasculaires des Monts de Czywczyn. - Bull. International de l'Académie Polonaise des Sciences et des Lettres, Cl. Math.-Nat., Ser. B (I), 1948: 117-181.

Sanda V., Öllerer K. \& Burescu P. (2008): Fitocenozele din România. Sintaxonomie, structură, dinamică şi evoluție. - Ed. Ars Docendi, Bucureşti.

Vorontsov D. P., Danylyk I. M., Kanarskyi Y. V. (2011): Vegetation cover of «Andromeda» raised bog (Ukrainian Carpathians). - J Biol. Syst. 3(3): 282287. 